\title{
BRICK WASTE A SUPPLEMENTARY CEMENTING MATERIAL IN AUTOCLAVED BUILDING PRODUCTS
}

\author{
D S Klimesch \\ M Gutovic \\ A Ray \\ University of Technology \\ Australia
}

\begin{abstract}
Fired-clay products such as bricks, tiles and pavers, are made in large volumes throughout the world and widely used as construction materials. A significant proportion of them end up being a waste material during either their production process or the demolition of buildings. High pressure steam curing or autoclaving is a proven and versatile method for utilising supplementary cementing materials such as fly-ash and blast furnace slag for the manufacture of cement-based building products. In this investigation, autoclaving has been used to treat blends of ordinary Portland cement with different amounts of ground brick waste. Our experimental data demonstrate the viability of this waste to be used by the construction industry as a supplementary cementing material. The paper presents results of salient engineering properties in relation to microstructural characteristics.
\end{abstract}

Keywords: Fired-clay products, Recycling, Tobermorite, Hydrogarnet, Mullite

D S Klimesch is a Research Fellow at the University of Technology, Australia.

M Gutovic is a PhD student at the University of Technology, Australia.

A Ray is an Associate Professor in the Department of Chemistry, Materials \& Forensic Sciences at the University of Technology, Australia. 


\section{INTRODUCTION}

The amount of Construction \& Demolition (C\&D) waste generated in the Sydney region alone exceeded 2 million tonnes in 2001. At present, an estimated $50 \%$ of this quantity is recycled for use in the construction of physical infrastructure, i.e. sub-base material for road works, and the rest is disposed of to landfills. A significant amount of C\&D waste produced in Sydney represents clay-brick waste, generated during their production process and from demolition activities. The development of sustainable, cost-effective technical solutions for the use of a high volume of clay brick waste will have a significant impact on the State's solid waste stream as has been highlighted by several recent investigations [1,2].

Previous work by the present authors has shown that the formation of $1.1 \mathrm{~nm}$ tobermorite, the principal binder of most autoclaved calcium silicate based building materials, is enhanced by the addition of finely ground brick waste to blends of Portland cement (OPC) and quartz sand $[3,4]$. To gain better insight into the behaviour of brick waste under autoclaving conditions, blends of OPC with different amounts of finely ground brick waste were prepared and evaluated for compressive strength and microstructural characteristics. The present article reports the findings of the effects of brick waste on phase formation and strength development.

\section{EXPERIMENTAL}

\section{Raw Materials}

The following raw materials were used:

(a) Goliath cement (OPC) containing $\mathrm{SiO}_{2} 20.0 \%, \mathrm{CaO} 64.2 \%, \mathrm{Al}_{2} \mathrm{O}_{3} 4.5 \%, \mathrm{Fe}_{2} \mathrm{O}_{3} 3.7 \%$, $\mathrm{SO}_{3} 3.5 \%$, and having a fineness index (Blaine) of $350 \mathrm{~m}^{2} / \mathrm{kg}$ was produced by Australian Cement, Auburn, NSW, Australia.

(b) Crushed brick waste less than $2.38 \mathrm{~mm}$, was derived from a major clay-brick manufacturer in Sydney, Australia. The method of grinding used to produce ground brick fines having a surface area comparable to that of quartz sand, as used in commercial practice, was dry ball milling. Table 1 depicts the major oxides of the brick fines as determined by X-ray fluorescence. The mineralogical composition was determined qualitatively using X-ray powder diffractometry (XRD) using JCPDS powder patterns. The major crystalline phases, in decreasing order of abundance were: quartz, cristobalite, mullite and hematite.

\section{Sample Preparation}

OPC-brick fines mixtures were prepared using a water-to-total solids ratio of 0.36 as this yielded comparable workability for all the mixtures. Brick fines were added at 0, 10, 20, 30, $40,50,60,70,80$ and 90 mass $\%$ as cement replacement. The chemical compositions of the pastes studied are presented in Table 2. Mechanical mixing was conducted in accordance with ASTM C 305-082. Pastes were cast into stainless steel moulds and consolidated on a vibratory table, followed by a 24 hour curing period in a moist cabinet. For each mix, three $50 \mathrm{~mm}$ cubes were made. Demoulded specimens were autoclaved for 8 hours, 6 hours of which were at $180^{\circ} \mathrm{C}$ under saturated steam. 
After autoclaving, all cubes were allowed to air dry for 48 hours followed by compressive strength testing. After compressive strength testing, fractured pieces from each of the three cubes per mix were oven dried at $103^{\circ}$ to $105^{\circ} \mathrm{C}$ overnight followed by disc milling for further analyses.

Table 1 Major oxides of brick fines used in this investigation

(major oxides are in mass percent)

\begin{tabular}{cc}
\hline \multicolumn{2}{c}{ MAJOR OXIDES } \\
\hline $\mathrm{SiO}_{2}$ & 69.7 \\
$\mathrm{Al}_{2} \mathrm{O}_{3}$ & 18.6 \\
$\mathrm{Fe}_{2} \mathrm{O}_{3}$ & 7.5 \\
$\mathrm{~K}_{2} \mathrm{O}$ & 1.88 \\
$\mathrm{MgO}$ & 0.95 \\
$\mathrm{Na} 2$ & 0.44 \\
$\mathrm{CaO}$ & 0.20 \\
\hline
\end{tabular}

Table 2 Chemical compositions of pastes studied.

Brick fines added are in mass percent

\begin{tabular}{cccc}
\hline $\begin{array}{c}\text { BRICK FINES } \\
\text { ADDED }\end{array}$ & $\begin{array}{c}\text { BULK MOLE } \\
\mathrm{Ca} / \mathrm{Si}\end{array}$ & $\begin{array}{c}\text { BULK MOLE } \\
\mathrm{Ca} /(\mathrm{Al}+\mathrm{Si})\end{array}$ & $\begin{array}{c}\text { BULK MOLE } \\
\mathrm{Al} /(\mathrm{Al}+\mathrm{Si})\end{array}$ \\
\hline 0 & 3.44 & 2.72 & 0.21 \\
10 & 2.48 & 1.94 & 0.22 \\
20 & 1.84 & 1.43 & 0.22 \\
30 & 1.38 & 1.07 & 0.23 \\
40 & 1.04 & 0.80 & 0.23 \\
50 & 0.77 & 0.59 & 0.23 \\
60 & 0.55 & 0.42 & 0.24 \\
70 & 0.38 & 0.29 & 0.24 \\
80 & 0.23 & 0.18 & 0.24 \\
90 & 0.11 & 0.08 & 0.24 \\
\hline
\end{tabular}

\section{Methods}

Thermal analysis was carried out on powdered samples using a TA-instruments SDT 2960 simultaneous differential thermal and thermogravimetric analyser (DTA-TGA) at a heating rate of $10^{\circ} \mathrm{C} / \mathrm{min}$ under flowing air $(20 \mathrm{~mL} / \mathrm{min})$ from $20^{\circ}$ to $1000^{\circ} \mathrm{C}$. Sample sizes were between 30 to $50 \mathrm{mg}$ and were packed into a Pt-Rh crucible with 20 taps. All DTA-TGA curves were evaluated using the TA instruments data analysis software as detailed by Klimesch and Ray [5]. The second derivative differential thermal curves (DDT) were used for peak temperature determinations [6]. X-ray diffraction (XRD) analyses were conducted on powdered specimens using a Siemens D5000 diffractometer and copper $\mathrm{K}_{\alpha 1}$ radiation from 3 to $60^{\circ} 2 \theta$ at $0.02^{\circ} 2 \theta$ per second. XRD patterns were $K_{\alpha 2}$ stripped and corrected for instrumental drift. Crystalline phases were identified using JCPDS powder patterns. Additionally, an X-ray line profile fitting program was used to determine integrated peak heights and areas as well as peak positions of major crystalline phases present. 
The amount of acid-insoluble residue (AIR) was used as a measure of total unreacted material, as detailed by Klimesch and Ray [7]. In addition, the residues from triplicate AIR analyses were combined and the chemical composition determined by Inductively Coupled Plasma Optical Emission Spectrometry by the Genalysis Laboratory Services Pty. Ltd., Western Australia.

\section{RESULTS AND DISCUSSION}

Figure 1 shows that the highest strengths were obtained for brick fines additions between 40 to 50 mass \%. Table 3 provides a summary of the phases identified by XRD and DTA.

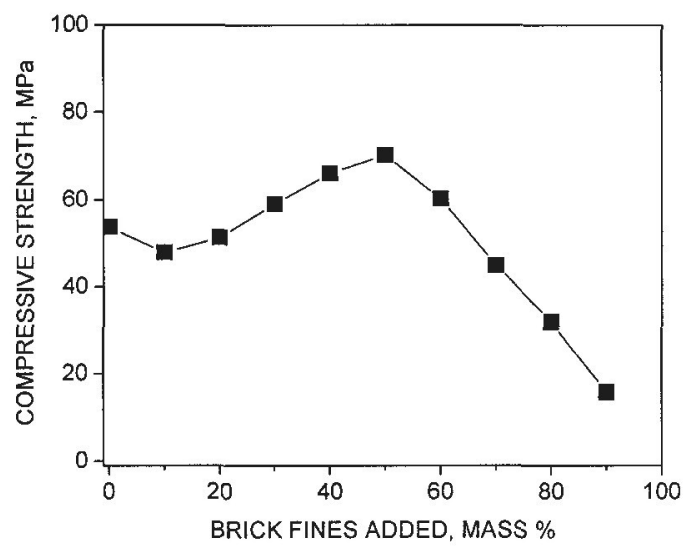

Figure 1 Average compressive strength of autoclaved OPC-brick fines mixtures.

Table 3 Phases identified by XRD and DTA.

Brick fines added are in mass percent

\begin{tabular}{cccccccc}
\hline $\begin{array}{c}\text { BRICK FINES } \\
\text { ADDED }\end{array}$ & C-S-Hs & Tob* & Hyd & $\mathrm{CH}$ & $\alpha-\mathrm{C}_{2}$ SH & $\mathrm{CaCO}_{3}$ & $\mathrm{Q}$ \\
\hline 0 & & & & & & & \\
10 & $\checkmark$ & $\mathrm{X}$ & $\checkmark$ & $\checkmark$ & $\checkmark$ & $\checkmark$ & $\mathrm{X}$ \\
20 & $\checkmark$ & $\checkmark$ & $\checkmark$ & $\checkmark$ & $\mathrm{X}$ & $\checkmark$ & $\checkmark$ \\
30 & $\checkmark$ & $\checkmark$ & $\checkmark$ & $\checkmark$ & $\mathrm{X}$ & $\checkmark$ & $\checkmark$ \\
40 & $\checkmark$ & $\checkmark$ & $\checkmark$ & $\checkmark$ & $\mathrm{X}$ & $\checkmark$ & $\checkmark$ \\
50 & $\checkmark$ & $\checkmark$ & $\checkmark$ & $\mathrm{X}$ & $\mathrm{X}$ & $\checkmark$ & $\checkmark$ \\
60 & $\checkmark$ & $\checkmark$ & $\checkmark$ & $\mathrm{X}$ & $\mathrm{X}$ & $\checkmark$ & $\checkmark$ \\
70 & $\checkmark$ & $\checkmark$ & $\checkmark$ & $\mathrm{X}$ & $\mathrm{X}$ & $\checkmark$ & $\checkmark$ \\
80 & $\checkmark$ & $\checkmark$ & $\mathrm{X}$ & $\mathrm{X}$ & $\mathrm{X}$ & $\checkmark$ & $\checkmark$ \\
90 & $\checkmark$ & $\mathrm{X}$ & $\mathrm{X}$ & $\mathrm{X}$ & $\mathrm{X}$ & $\checkmark$ & $\checkmark$ \\
\hline
\end{tabular}

* see text for discussion

$\mathrm{C}-\mathrm{S}-\mathrm{Hs}=$ calcium silicate hydrates; $\mathrm{Tob}=$ tobermorite; $\mathrm{Hyd}=$ hydrogarnet $; \mathrm{CH}=\mathrm{Ca}(\mathrm{OH})_{2} ; \alpha-\mathrm{C}_{2} \mathrm{SH}=$ alphadicalcium silicate hydrate; $Q=$ quartz 
i. In relation to Table 3, the following points are noteworthy: Tobermorite was considered absent when the diffraction line due to the (002) peak at around $1.1 \mathrm{~nm}$ was not discernible. It is known that this peak is affected in height by the degree of order parallel to the c-direction, and that both absolute and relative intensities of peaks in the tobermorite pattern vary with the $\mathrm{Ca} / \mathrm{Si}$ ratio and the degree of Al-substitution $[8,9]$.

ii. C-S-H with main d-spacings at around $0.304 \mathrm{~nm}$ and $0.73 \mathrm{~nm}$, referred to as "fibrous C$\mathrm{S}-\mathrm{H}^{\prime}$ by Kalousek [10], was present in all samples. The XRD peak in the $0.300 \mathrm{~nm}$ region due to $\mathrm{CaCO}_{3}$ interferes with reflections attributable to $\mathrm{C}-\mathrm{S}-\mathrm{H}$.

The crystallinity of tobermorite was determined from XRD data by the peak intensity ratio of the $0.308 \mathrm{~nm}$ and $1.1 \mathrm{~nm}\left(\mathrm{H}_{0.308} / \mathrm{H}_{1.1}\right)$ reflections [11]. In this context, the higher this ratio the less crystalline the material. The variations in the integrated area (arbitrary units) of the $1.1 \mathrm{~nm}$ peak and the ratio of peak heights of the $0.308 \mathrm{~nm}$ and $1.1 \mathrm{~nm}$ peaks are depicted in Figure 2. Figures 3 and 4 show the variations in the integrated areas of the $0.304 \mathrm{~nm}$ (Figure 3 ) and $0.505 \mathrm{~nm}$ (Figure 4) peaks attributable to C-S-H and hydrogarnet, respectively.

1. From XRD data, the presence of Al-bearing tobermorite (Al-tobermorite) was manifested by the position of the (002) peak, the d-spacing ranging from $1.13 \mathrm{~nm}$ to $1.14 \mathrm{~nm}$. Figure 2 shows that brick fines additions of 20 and 30 mass \% promoted the formation of poorly crystalline Al-tobermorite. Additions of 40 to 60 mass $\%$ promoted the formation of highly crystalline Al-tobermorite, the amount reaching a maximum at 40 mass \% followed by a steady decrease from 50 to 60 mass \%. For additions greater than 60 mass \%, Al-tobermorite amount and its crystallinity decreased significantly. The variations in Al-tobermorite amount can be explained, at least in part, in terms of the decreasing bulk $\mathrm{Ca} / \mathrm{Si}$ and $\mathrm{Ca} /(\mathrm{Al}+\mathrm{Si})$ molar ratios (Table 2). In other words, with decreasing OPC:brick fines ratio, the availability of $\mathrm{CaO}$ from cement decreases resulting in the formation of fewer hydration products.

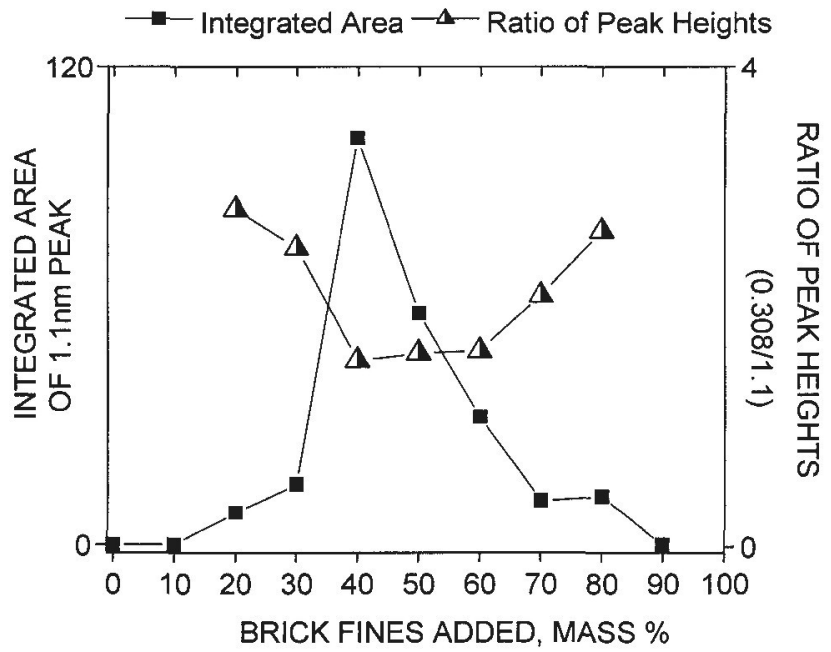

Figure 2 Showing the variations in the integrated area (arbitrary units) of the $1.1 \mathrm{~nm}$ peak and the ratio of peak heights of the $0.308 \mathrm{~nm}$ and $1.1 \mathrm{~nm}$ peaks versus brick fines content. 


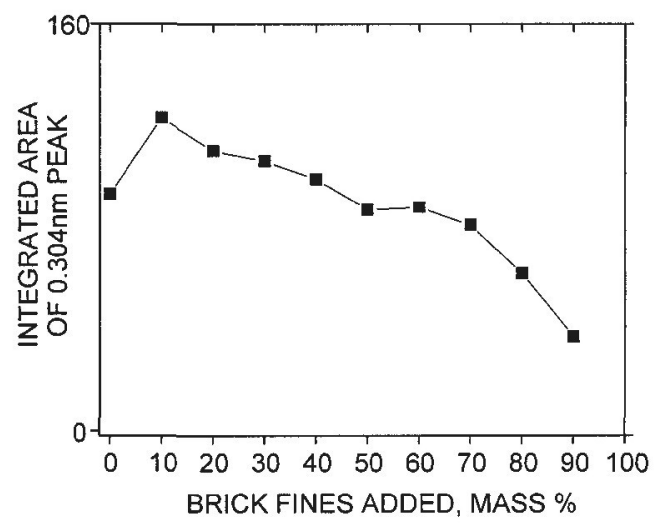

Figure 3 Variation in the integrated area of the $0.304 \mathrm{~nm}$ peak attributable to C-S-H with increasing brick fines addition.

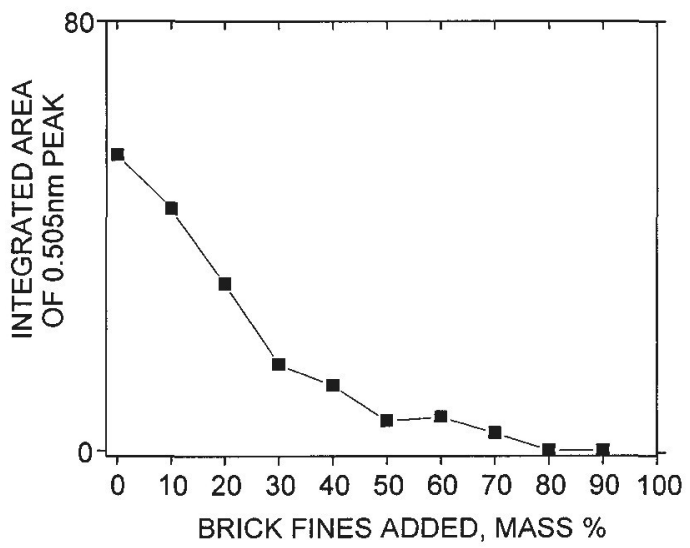

Figure 4 Variation in the integrated area of the $0.505 \mathrm{~nm}$ peak attributable to hydrogarnet

(where present) with increasing brick fines addition.

2. The formation of "fibrous C-S-H" diminished slightly and then appreciably for brick fines additions of 20 to 50 mass \% and greater than 60 mass \%, respectively (Figure 3 ). Concurrently, the amount of hydrogarnet decreased monotonically for brick fines additions of 10 to 70 mass \%. Again, these results can be explained, at least in part, in terms of the decreasing bulk $\mathrm{Ca} / \mathrm{Si}$ and $\mathrm{Ca} /(\mathrm{Al}+\mathrm{Si})$ molar ratios (Table 2$)$.

From the standpoint of strength development, the present data reinforce previous findings in that: first, there exists a good correlation between the total sum of tobermorite and C-S-H present and the compressive strength; and second, some optimum degree of binder crystallinity exists [12]. In this context, the present data show that the highest strengths obtained (Figure 1) correspond to the presence of highly crystalline tobermorite (Figure 2) and "fibrous C-S-H" (Figure 3). 
3. It may be noted that the total bulk composition, i.e. total bulk $\mathrm{Ca} /(\mathrm{Al}+\mathrm{Si})$ molar ratio, does not equal the total reacted composition, since unreacted brick fines remained in all the specimens. More specifically the amount of unreacted material, as determined by the acid-insoluble residue (AIR), ranged from $2.7 \%$ to $75.1 \%$ for $10 \%$ to $90 \%$ brick fines additions, respectively. From analyses of the oxide composition of the $\mathrm{AIR}$, the actual reacted $\mathrm{Ca} /(\mathrm{Al}+\mathrm{Si})$ molar ratios have been determined and are presented in Figure 5. From this figure it is evident that for reacted $\mathrm{Ca} /(\mathrm{Al}+\mathrm{Si})$ molar ratios between 1.05 and 0.92 , maximum strength development occurred with highly crystalline tobermorite being the main binder (Figure 2) along with "fibrous C-S-H" (Figure 3).

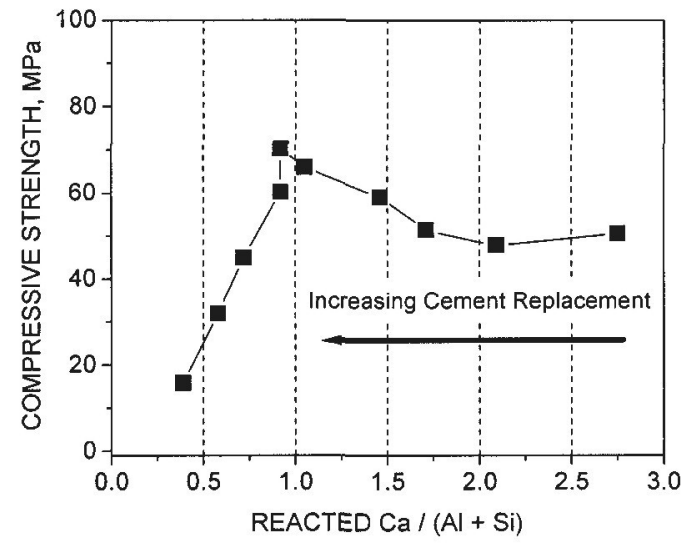

Figure 5 Showing the variations of reacted $\mathrm{Ca} /(\mathrm{Al}+\mathrm{Si})$ molar ratio versus compressive strength for increasing cement replacement with brick fines additions.

\section{CONCLUSIONS}

1. Brick fines additions of 20 and 30 mass $\%$ promoted the formation of poorly crystalline Al-tobermorite while the compressive strength increased concurrently. Additions of 40 to 60 mass \% promoted the formation of highly crystalline Al-tobermorite, the amount reaching a maximum at 40 mass \% followed by a steady decrease from 50 to 60 mass $\%$. The compressive strength reached a maximum between 40 to 50 mass \% brick fines additions. For additions greater than 60 mass \%, Al-tobermorite amount and its crystallinity decreased significantly. Concurrently, the formation of "fibrous C-S-H" diminished slightly and then appreciably for brick fines additions of 20 to 50 mass \% and greater than 60 mass $\%$, respectively.

2. For reacted $\mathrm{Ca} /(\mathrm{Al}+\mathrm{Si})$ molar ratios between 1.05 and 0.92 , maximum strength development occurred with highly crystalline tobermorite being the main binder along with "fibrous C-S-H".

3. The use of waste brick fines in combination with OPC for the production of hydrothermally cured calcium silicate based materials is a viable option for the future. 


\section{REFERENCES}

1. BAKOSS, S.L., SRI RAVINDRARAJAH, R., Recycled C\&D Materials for Use in Roadworks and other Local Government Activities: Scoping Report, Centre for Built Infrastructure Research, University of Technology, Sydney, 1999, pp 1-68.

2. KLIMESCH, D.S., SRI RAVINDRARAJAH, R., BAKOSS, S.L., New Technologies for use of Recycled Brick as Construction Material: Final Report to NSW Waste Boards, Centre for Built Infrastructure Research, University of Technology, Sydney, 2001, pp 1-66.

3. KLIMESCH, D.S., RAY, A., Incorporating brick fines in cement-based building materials: Proceedings of the International Conference on Composites in Construction, Figueiras et al. (Eds.), Porto, 2001, pp 47-49.

4. KLIMESCH, D.S., RAY, A., GUERBOIS, J.P., Differential scanning calorimetry evaluation of autoclaved cement based building materials made with construction and demolition waste: Thermochimica Acta, Vol. 389, 2002, pp 195-198.

5. KLIMESCH, D.S., RAY, A., The use of DTA/TGA to study the effects of ground quartz with different surface areas in autoclaved cement:quartz pastes. Part 1: A method for evaluating DTA/TGA results: Thermochimica Acta, Vol. 289, 1996, pp 41-54.

6. KLIMESCH, D.S., RAY, A., Use of the second-derivative differential thermal curve in the evaluation of cement-quartz pastes with metakaolin addition autoclaved at $180^{\circ} \mathrm{C}$ : Thermochimica Acta, Vol. 307, 1997, pp167-176.

7. KLIMESCH, D.S., RAY, A., Metakaolin additions to autoclaved cement-quartz pastes: Evaluation of the acid-insoluble residue: Advances in Cement Research, Vol. 9, 1997, pp 157-165.

8. DYCZEK, J.R.L., TAYLOR, H.F.W., X-ray determination of tobermorite, quartz, and alpha-dicalcium silicate hydrate in autoclaved calcium silicate materials: Cement and Concrete Research, Vol. 1, 1971, pp 589-605.

9. KALOUSEK, G.L., Crystal chemistry of hydrous calcium silicates: I, Substitution of aluminum in lattice of tobermorite: Journal of the American Ceramic Society, Vol. 40, 1957, pp 74-80.

10. KALOUSEK, G.L., Tobermorite and related phases in the system $\mathrm{CaO}-\mathrm{SiO}_{2}-\mathrm{H}_{2} \mathrm{O}$ : Journal of the American Ceramic Society, Vol. 51, 1955, pp 989-1011.

11. SUN, B., SU, E., The crystallinity and rate of carbonation of hydrated calcium silicates: Guisuanyan Xuebao, Vol. 12, 1984, pp 281-285.

12. TAYLOR, H.F.W., Cement Chemistry, 2nd ed, Thomas Telford, London, 1997, p 342. 